STUDIA I PRACE WYDZIAŁU NAUK EKONOMICZNYCH I ZARZĄDZANIA NR 40, T. 2

DOI: $10.18276 / \operatorname{sip} .2015 .40 / 2-14$

\author{
Mariola E. Zalewska* \\ Waldemar Kozioł ${ }^{*}$ \\ Uniwersytet Warszawski
}

\title{
W POSZUKIWANIU MIAR EFEKTYWNOŚCI INWESTYCJI NA RZECZ ŚRODOWISKA
}

\section{STRESZCZENIE}

W artykule naszkicowano zarys problematyki pomiaru efektywności inwestycji na rzecz środowiska. Przedstawiono uproszczony schemat relacji zachodzących między społeczeństwem a środowiskiem z uwzględnieniem systemu wskaźników opisujących te relacje. Zwrócono uwagę na użyteczność wyodrębnienia inwestycji na rzecz środowiska jako jednego $\mathrm{z}$ aspektów relacji między społeczeństwem i środowiskiem. Artykuł kończy się przykładem, w którym wykazano, że nawet tak rozbudowana baza danych, jak Eurostat, nie wystarcza do oceny efektywności inwestycji na rzecz środowiska na poziomie krajów.

Słowa kluczowe: system wskaźników; efektywność inwestycji, środowisko, zrównoważony rozwój

\section{Wprowadzenie}

Całokształt działalności człowieka, zarówno gospodarczej, jak i społeczno-kulturalnej, opiera się na relacji między społeczeństwem a światem biofizycz-

\footnotetext{
*Adres e-mail: zalewska@wz.uw.edu.pl.

** Adres e-mail: wkoziol@wz.uw.edu.pl.
} 
nym (środowiskiem). Jedną z form działań podejmowanych przez społeczeństwo na rzecz środowiska są inwestycje w ochronę środowiska. Podobnie jak ma to miejsce w przypadku innych inwestycji, angażowane są ograniczone zasoby służące realizacji określonych celów ekonomicznych, społecznych i środowiskowych (ekologicznych). Naturalne jest więc pytanie o pomiar ich efektywności. Bardzo często zachodzi potrzeba selekcji inwestycji. Na jakiej podstawie dokonywać wyboru? Zdaniem autorów kluczową sprawą jest dążenie do opracowania wiarygodnych metod szacowania efektywności inwestycji w ochronę środowiska. Uwarunkowania decyzji inwestycyjnych w dziedzinie ochrony środowiska zostały omówione z wykorzystaniem uzupełnionego przez autorów modelu interakcji społeczeństwa i środowiska zaproponowanego przez szwajcarski urząd statystyczny.

Analizie efektywności inwestycji na rzecz środowiska poddawane są najczęściej pojedyncze inwestycje lub inwestycje sektorowe. W artykule podjęto próbę odpowiedzi na pytanie, czy możliwe jest porównanie efektywności pomiędzy krajami na podstawie danych dostępnych w bazie Eurostat. Wybrano jeden przykład celu inwestycyjnego na poziomie kraju - redukcję emisji tlenków siarki (SOX). Przeprowadzono argumentację za używaniem stosunku poziomu emisji danego czynnika zanieczyszczającego atmosferę do poziomu emisji ditlenku węgla $\left(\mathrm{CO}_{2}\right)$, jako miernika wpływu inwestycji na redukcję emisji badanego czynnika. Następnie zademonstrowano, że pomiar efektywności za pomocą danych Eurostat nie jest wykonalny z powodu braku możliwości oceny wielkości ponoszonych przez dany kraj nakładów. Wykazanie, że jest tak nie tylko w przypadku wybranego przykładu przekracza ramy niniejszego artykułu. W artykule wykorzystano ogólnodostępne bazy danych: Eurostat i OFS.

\section{Rodzaje inwestycji na rzecz środowiska}

Inwestycje na rzecz środowiska mogą być różnej natury: począwszy od zachowania światowego dziedzictwa ${ }^{1}$, przez niepogarszanie stanu środowiska (zachowania bioróżnorodności, czystości rzek, czystości powietrza), ograniczenia wykorzystania zasobów naturalnych, do zmniejszenia emisji wytwarzania odpadów i prze-

\footnotetext{
1 Valeur économique du Parc national des Virunga, WWF, Gland Suisse 2013, https://assets.wwf. ch/downloads/valeur_economique_du_parc_national_des_virunga_lr.pdf (dostęp 25.04.2015).
} 
twarzania odpadów. Inwestycje na rzecz środowiska można podzielić ze względu na następujące kryteria:

- zasięg oddziaływania inwestycji: globalny, międzynarodowy, krajowy, regionalny, lokalny, mieszany $\mathrm{i}$ inne,

- strukturę finansowania inwestycji: środki własne, fundusze celowe, środki budżetowe, środki z zagranicy, fundusze ekologiczne, kredyty i pożyczki, środki gospodarstw domowych i organizacji społecznych i inne,

- przedmiotowe przeznaczenie inwestycji: ochrona wód i gospodarka ściekowa, ochrona klimatu i powietrza atmosferycznego, ochrona powierzchni ziemi i ochrona gleb, gospodarka odpadami, ochrona krajobrazu i bioróżnorodności biologicznej, ochrona przed hałasem, promieniowaniem i wibracjami, a także działania w zakresie oszczędzania energii,

- metody organizacyjne realizacji inwestycji²: model prywatny, model publiczny, model prywatno-publiczny (PPP),

- podmioty finansujące inwestycje: jednostki budżetowe, przedsiębiorstwa, samorządy, organizacje społeczne, gospodarstwa domowe,

- efekty rzeczowe inwestycji dla sektorów gospodarki zgodnie z klasyfikacją $\mathrm{PKD}^{3}$ np.: rolnictwo, leśnictwo i rybołówstwo, przemysł wydobywczy, produkcja i dystrybucja energii i wody, gospodarowanie odpadami, budownictwo, transport, składowanie, zakwaterowanie i wyżywienie, działalność finansowa i ubezpieczeniowa, obsługa nieruchomości i inne,

- typ inwestycji: przedsięwzięcia zintegrowane zapobiegające zanieczyszczeniom i prowadzące do zmniejszenia ich ilości dzięki modyfikacji procesów technologicznych, tzw. przedsięwzięcia „końca rury” - skierowane na neutralizację zanieczyszczeń nieingerujące $\mathrm{w}$ proces produkcyjny ${ }^{4}$ oraz inne, np. o charakterze edukacyjnym, informacyjnym, naukowym.

${ }^{2}$ D. Handys, Partnerstwo publiczno-prywatne jako forma racjonalizacji wydatków inwestycyjnych gmin, w: Ekonomiczne i prawne problemy racjonalizacji wydatków publicznych. Kontrowersje wokót wydatkowania środków publicznych $w$ wybranych dziedzinach funkcjonowania państwa i gospodarki narodowej, red. J. Głuchowski, A. Pomorska, J. Szołno-Koguc, t. II, Wydawnictwo Uniwersytetu Marii Curie-Skłodowskiej, Lublin 2005, s. 97.

${ }^{3}$ Rozporządzenie Rady Ministrów z dnia 24.12.2007 r. w sprawie Polskiej Klasyfikacji Działalności (PKD) (DzU z 2007 r., nr 251, poz. 1885; DzU z 2009 r., nr 59, poz. 489).

${ }^{4}$ Ochrona środowiska, GUS, Warszawa 2014, s. 399. 


\section{Uwarunkowania decyzji inwestycyjnych w dziedzinie ochrony środowiska}

Wybory inwestycyjne w każdym obszarze, również środowiskowym, dotyczą przedmiotu (w co?), miejsca (gdzie?), czasu (kiedy?) oraz wielkości (ile?) inwestycji. Powinny być poprzedzone analizami efektywności (ex ante) różnych możliwości inwestycyjnych oraz dokonaniem ich oceny z punktu widzenia efektywności inwestycji. Inwestycja oznacza zaangażowanie zasobów, które mają w przyszłości przynieść oczekiwane efekty. Korzyściami mogą być: zachowanie dziedzictwa przyrody, ograniczenie zużycia zasobów, zmniejszenie odpadów, zysk, poprawa jakości życia społeczeństwa itp. ${ }^{5}$ Efekty inwestycji dla środowiska współistnieją również w obszarach ekonomicznym i społecznym, stąd wyróżnia się co najmniej trzy metody oceny wartościowej efektywności projektów: finansową, ekonomiczną i społeczną ${ }^{6}$. Cele i ocena ex post efektywności inwestycji na rzecz środowiska są pochodną wcześniejszych wyborów politycznych, tzn. założonych celów dla inwestycji. Dla oceny inwestycji tak ex post, jak i ex ante kluczowe jest zrozumienie, że jej oczekiwana efektywność ma kilka wymiarów i odnosi się do dynamicznie zmieniającego się układu interakcji zachodzących między społeczeństwem i środowiskiem, co schematycznie przedstawiono na rysunku 1, który jest zmodyfikowaną wersją modelu zaproponowanego przez szwajcarski urząd statystyczny $\mathrm{OFS}^{7}$. Numery przy poszczególnych elementach tego schematu nie oznaczają sekwencji działań. Punkty 1-5 uzupełniono, odwołując się do inwestycji na rzecz środowiska (punkt 6), które można wyróżnić wśród reakcji (działań) społeczeństwa, np. inwestycje w energię odnawialną, ograniczające emisję zanieczyszczeń, odzyskiwanie odpadów itp. Inwestycje na rzecz środowiska mogą wpływać zarówno na sposób czerpania zasobów ze środowiska (reprezentowany na rysunku 1 przez górną, skierowaną w lewo szeroką strzałkę), jak i na strumień odpadów oddawanych do środowiska (reprezentowany przez dolną, skierowaną w prawo szeroką strzałkę).

${ }^{5}$ A. Zalewski, Metody oceny projektów inwestycyjnych, w: Ocena i wycena zasobów przyrodniczych, red. J. Szyszko, J. Rylke, P. Jeżewski, I. Dymitryszyn, Wydawnictwo Szkoły Głównej Gospodarstwa Wiejskiego, Warszawa 2013, s. 354.

\section{${ }^{6}$ Ibidem.}

${ }^{7}$ Environnement. Statistique de poche 2013, Office fédéral de la statistique (OFS), Neuchâtel 2013, www.bfs.admin.ch/bfs/portal/fr/index.html (dostęp 19.04.2015). 
Rysunek 1. Relacje między społeczeństwem a środowiskiem

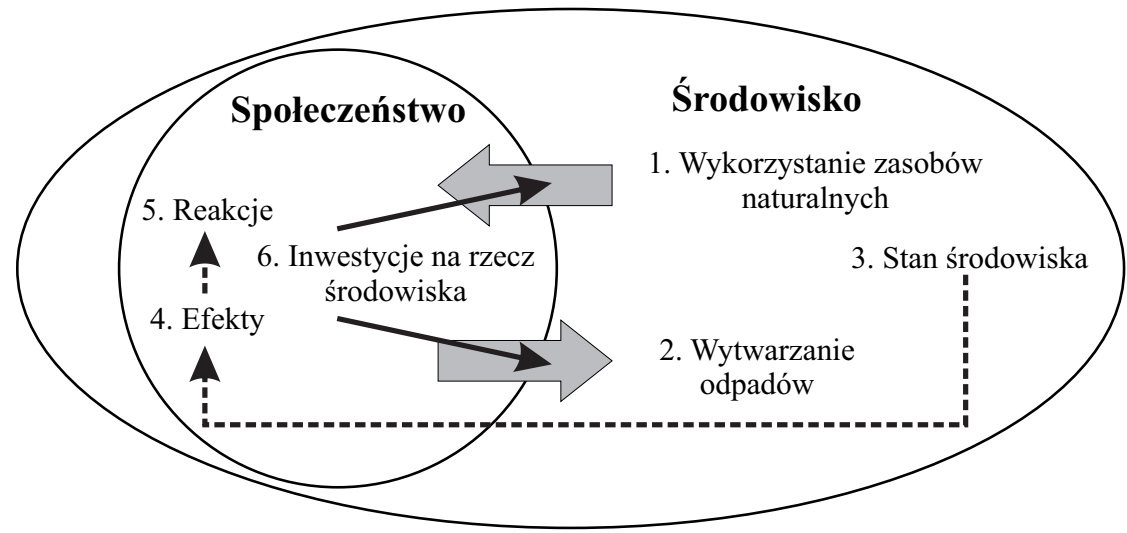

Źródło: opracowanie własne na podstawie OFS?

\section{Efektywność inwestycji środowiskowych}

Poprawa stanu środowiska ma pozytywny wpływ na inne wymiary życia społeczno-gospodarczego, a nawet dzięki poprawie jakości życia na konkurencyjność regionów i krajów ${ }^{8}$. W raporcie Europejskiej Agencji Środowiska ${ }^{9}$ wskazano, że kraje UE powinny zacząć stosować bardziej zintegrowane podejście do rozwiązywania systemowych problemów związanych ze środowiskiem.

Efekty inwestycji środowiskowych przenikają praktycznie wszędzie tam, gdzie mamy do czynienia z aktywnością człowieka, choć często są one wskazywane intuicyjnie z braku właściwych narzędzi pomiaru oddziaływania. Ponadto są odłożone w czasie, co stwarza istotne problemy przy pomiarze efektywności inwestycji w środowisko. W konsekwencji często oceny efektywności dokonuje się w „klasyczny” sposób, ograniczając się do oceny finansowej. Czy jest to prawidłowe? Z pewnością niewystarczające. Ocena finansowa projektu jest oparta na analizie opłacalności

8 The European Environment - State and Outlook 2015: Synthesis Report, European Environment Agency EEA, Copenhagen 2015, www.eea.europa.eu/soer (dostęp 22.04.2015).

9 The European Environment - State and Outlook 2010: Assessment of Global Megatrends EEA, European Environment Agency, Copenhagen 2011, www.eea.europa.eu/soer/europe-and-the-world/ megatrends (dostęp 22.04.2015). 
i zyskowności dla inwestora. Nie obejmuje całości kosztów i korzyści inwestycji dla gospodarki narodowej. Dodatkowo projekty przynoszące efekty trudno wymierne lub niewymierne wartościowo są często oceniane wyłącznie na podstawie analizy efektywności kosztowej.

Dla właściwej oceny proponowanego projektu inwestycyjnego i możliwych opcji jego realizacji (ex ante), jak i skutków jego realizacji (ex post) kluczowy jest właściwy dobór miar efektywności, a więc dobór wskaźników opisujących pożądane i niepożądane skutki zmiany relacji społeczeństwo-środowisko, jakie będą miały miejsce w wyniku realizacji projektu. W zależności od stawianych projektowi celów można wskazać miary finansowe, ekonomiczne, społeczne oraz środowiskowe (ekologiczne).

W praktyce trudno pominąc którykolwiek z wskazanych wymiarów, co oznacza, że efektywność inwestycji mierzona będzie poprzez grupę obejmujących je miar. J.E. Stiglitz ${ }^{10}$ i inni autorzy raportu Komisji ds. Pomiaru Wydajności Ekonomicznej i Postępu Społecznego potwierdzają potrzebę wykorzystania różnych mierników do wielorakich celów ${ }^{11}$.

Najistotniejsze znaczenie w doborze miar efektywności będzie miało określenie kluczowych celów projektu oraz oczekiwanych pomocniczych skutków jego realizacji. Innymi słowy pomiar efektywności ma być realizowany z punktu widzenia kluczowych i pomocniczych celów projektu ${ }^{12}$.

Można wskazać dwa najważniejsze ograniczenia w budowie racjonalnych systemów pomiaru efektywności projektów inwestycyjnych ukierunkowanych na ochronę środowiska. Pierwszym jest długi okres oraz odroczone wyniki realizacji inwestycji. Stanowi to bardzo istotne ograniczenie metod bazujących na zdyskontowanych strumieniach korzyści ${ }^{13}$. Drugim ograniczeniem jest występowanie niemierzalnych lub trudno mierzalnych czynników (również skutków) wpływających na jakość życia mieszkańców. Niezwykle często oba te ograniczenia występują wspól-

10 J.E. Stiglitz, A. Sen, J-P. Fitoussi, Btad pomiaru. Dlaczego PKB nie wystarcza, PTE, Warszawa 2013, s. 95-135.

11 M.E. Zalewska, Jak mierzyć zrównoważony rozwój Polski?, w: Modele ustroju społeczno-gospodarczego. Kontrowersje i dylematy, red. E. Mączyńska, PTE, Warszawa 2015, s. 400.

${ }^{12}$ Ch. Gessner, W.F. Schultz, M. Kreeb, What Is a Good Strategy for Sustainable Development? A Draft Set of Evaluation Criteria, „Greener Management International” 2002, No. 36, www.highbeam. com (dostęp 18.03.2015).

${ }^{13}$ E.F. Brigham, Podstawy zarzadzania finansami, t. 2, PWE, Warszawa 1996, s. 53-74. 
nie. Można również wymienić ${ }^{14}$ powody metodologiczne, które w znaczący sposób ograniczają analizę porównawczą efektywności inwestycji na rzecz środowiska, wskazując np. na brak danych statystycznych lub ich niską jakość albo fakt, że pozyskiwane dane są dostępne tylko w krótkich okresach.

Sytuacja jest jeszcze bardziej skomplikowana w przypadku oceny efektywności polityki regionalnej lub krajowej dotyczącej inwestycji i strategii związanych $\mathrm{z}$ ochroną środowiska. Ponieważ bezwzględna ocena efektywności jest w takim przypadku praktycznie niewykonalna, potrzebne jest porównanie z innymi organizmami (regionami lub krajami).

\section{Próba oceny efektywności redukcji emisji tlenków siarki w krajach UE}

Jednym z ważnych aspektów negatywnego wpływu na środowisko jest poziom emisji tlenków siarki (SOX), który w oczywisty sposób wiąże się z poziomem emisji dwutlenku węgla $\left(\mathrm{CO}_{2}\right)$. Redukcja emisji $\mathrm{CO}_{2}$ może być spowodowana np. załamaniem koniunktury gospodarczej ${ }^{15}$. Dlatego miarą skuteczności metod ograniczania emisji SOX w procesach spalania powinien być stosunek poziomu emisji SOX do poziomu emisji $\mathrm{CO}_{2}$. Dane dotyczące wielkości emisji gazów znajdują się w bazie danych Eurostat dla lat 2008-2012 (dla większości krajów UE) i pozwalają na ocenę skuteczności redukcji tych emisji. Jednak w celu uzyskania miary efektywności potrzebna jest informacja o wielkości nakładów. Niestety nie ma jej w bazie danych Eurostat. Znajdujący się tam wolumen nakładów rządowych na redukcję zanieczyszczeń ${ }^{16}$ nie jest poszukiwaną wielkością. Na rysunku 2, na osi pionowej, odłożona jest względna zmiana stosunku poziomów emisji $\mathrm{SOX}$ i $\mathrm{CO}_{2}$ (wartość stosunku w roku 2012 podzielona przez wartość w roku 2008), czyli proponowana przez nas miara skuteczności redukcji emisji SOX, natomiast na osi poziomej odłożona jest właśnie wysokość nakładów rządowych na redukcję zanieczyszczeń poniesionych w latach 2008-2012.

${ }^{14}$ F. Iraldo, F. Testa, M. Melis, M. Frey, A Literature Review on the Links between Environmental Regulation and Competitiveness, „Environmental Policy and Governance” 2011, Vol. 21, No. 3, s. 210-222.

15 M.E. Zalewska, Zrównoważona konsumpcja i produkcja - nierówności w krajach Unii Europejskiej, w: „, Nierówności Społeczne a Wzrost Gospodarczy”, z. 42 (2), Uniwersytet Rzeszowski, Rzeszów 2015, s. 144-149.

${ }^{16}$ Wskaźnik Environmental Protection Expenditure of General Government by COFOG Groups and Economic Transactions [env_ac_cofog]: GF0503 - Pollution Abatement, Eurostat 2015, http://appsso.eurostat.ec.europa.eu/nui/show.do?lang=en\&dataset=env_ac_cofog (dostęp 7.03.2015). 
Rysunek 2. Względna zmiana stosunku poziomów emisji SOX i $\mathrm{CO}_{2}$ (wartość w roku 2012 podzielona przez wartość w roku 2008) dla wybranych krajów europejskich względem sumarycznych rządowych nakładów na redukcję zanieczyszczeń w latach 2008-2012

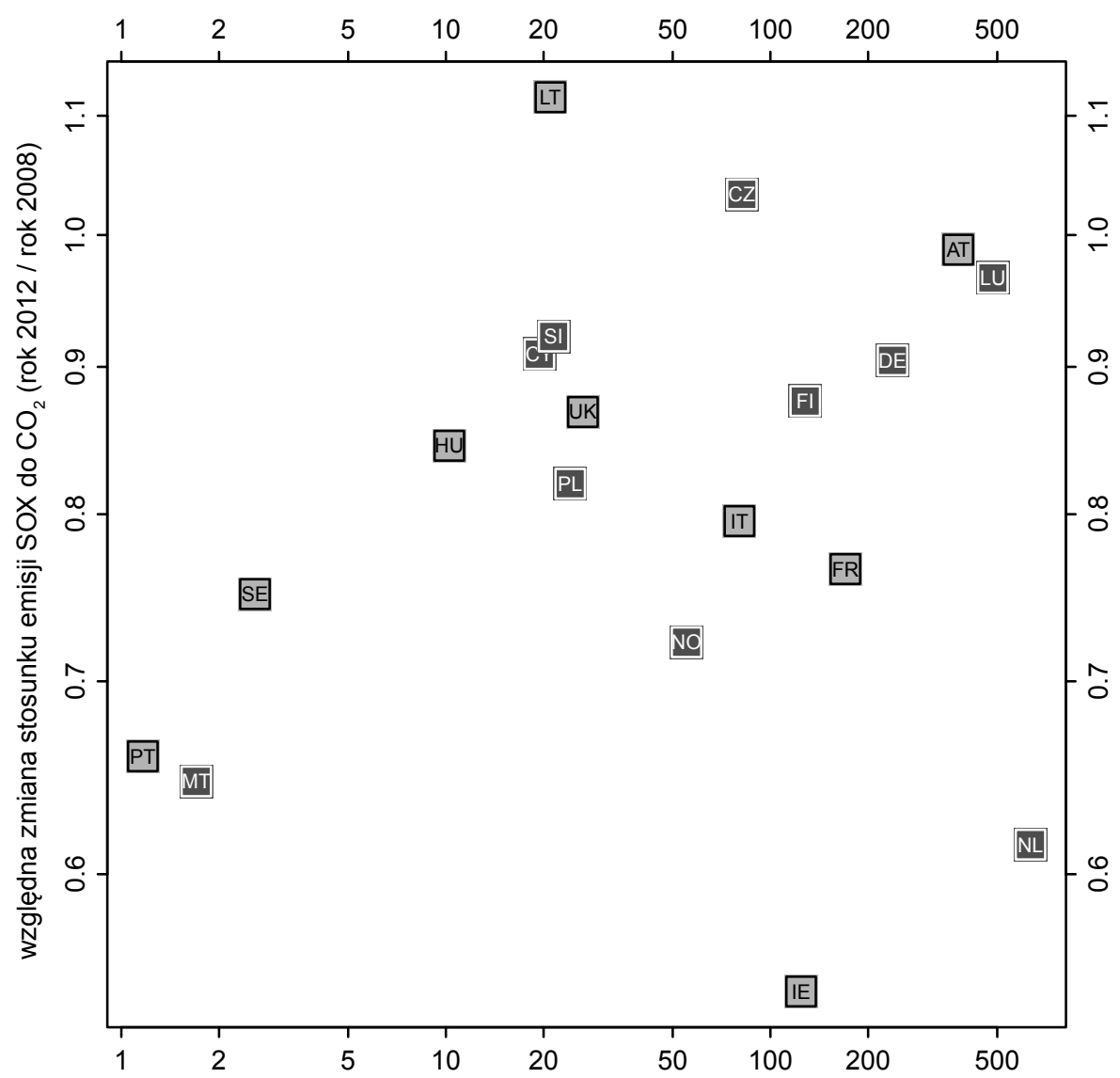

sumaryczne (2008-2012) rządowe nakłady na ograniczenie zanieczyszczeń (euro na mieszk.)

Źródło: opracowanie własne na podstawie bazy danych Eurostat.

Kraje o poziomie emisji $\mathrm{CO}_{2}$ (na jednego mieszkańca w 2012 roku) większym od średniej (dla pokazanej grupy państw) są zaznaczone za pomocą ciemnych kwadratów (z jasnym symbolem i ramką), a te o mniejszym - za pomocą jasnych kwadratów (z ciemnym symbolem i ramką). Widać wyraźnie, że największe obniżenie omawianego stosunku (SOX/CO 2$)$ uzyskano w Irlandii (IE), Holandii (NL), na Malcie 
(MT) oraz w Portugalii (PT). Poziom nakładów, choć największy dla Holandii oraz stosunkowo duży dla Irlandii, jest najmniejszy dla Portugalii i Malty. Nie świadczy to jednak o osiąganiu tym lepszych rezultatów, im mniejsze są nakłady rządowe, tylko o uzyskiwaniu poprawy dzięki działaniom niezwiązanym z tymi nakładami.

\section{Podsumowanie}

Szacowanie efektywności inwestycji środowiskowych jest ważne, ale bardzo trudne. W wielu wypadkach obiektywna ocena nie jest w ogóle możliwa ze względu na brak możliwości uwzględnienia wszystkich skutków takich inwestycji lub rozłożenie tych skutków w czasie. Nawet w prostych przypadkach, takich jak pomiar efektywności redukcji emisji SOX, okazuje się, że ogólnie dostępne bazy danych nie są wystarczające do porównanie tej efektywności dla poszczególnych krajów europejskich.

\section{Literatura}

Brigham E.F., Podstawy zarzadzania finansami, t. 2, PWE, Warszawa 1996.

Environmental Protection Expenditure of General Government by COFOG Groups and Economic Transactions [env_ac_cofog]: GF0503 - Pollution Abatement, Eurostat 2015, http:// ec.europa.eu/eurostat/cache/metadata/en/env_ac_cofog_esms.htm (dostęp 7.03.2015).

Environnement. Statistique de poche 2013, Office fédéral de la statistique OFS 2013, Neuchâtel 2013 (dostęp 19.04.2015).

Gessner Ch., Schultz W.F., Kreeb M., What is a Good Strategy for Sustainable Development? A Draft Set of Evaluation Criteria, „Greener Management International” 2002, nr 36 (Special Issue on Evaluating Sustainable Development Policy).

Handys D., Partnerstwo publiczno-prywatne jako forma racjonalizacji wydatków inwestycyjnych gmin, w: Ekonomiczne i prawne problemy racjonalizacji wydatków publicznych. Kontrowersje wokót wydatkowania środków publicznych $w$ wybranych dziedzinach funkcjonowania państwa i gospodarki narodowej, red. J. Głuchowski, A. Pomorska, J. Szołno-Koguc, t. II, Wydawnictwo Uniwersytetu Marii Curie-Skłodowskiej, Lublin 2005.

Iraldo F., Testa F., Melis M., Frey M., A Literature Review on the Links between Environmental Regulation and Competitiveness, „Environmental Policy and Governance” 2011, Vol. 21, No. 3.

Ochrona środowiska, GUS, Warszawa 2014.

Perkins F., Practical Cost-Benefit Analysis, Macmillan Education, Melbourne1994. 
Rozporzadzenie Rady Ministrów z dnia 24.12.2007 r. w sprawie Polskiej Klasyfikacji Działalności (PKD) (DzU z 2007 r., nr 251, poz. 1885; DzU z 2009 r., nr 59, poz. 489).

Stiglitz J.E., Sen A., Fitoussi J-P., Btad pomiaru. Dlaczego PKB nie wystarcza, PTE, Warszawa 2013.

The European Environment - State and Outlook 2010: Assessment of Global Megatrends EEA, European Environment Agency, Copenhagen 2011, www.eea.europa.eu/soer/ europe-and-the-world/megatrends (dostęp 22.04.2015).

The European Environment - State and Outlook 2015: Synthesis Report, European Environment Agency EEA, Copenhagen 2015, www.eea.europa.eu/soer (dostęp 22.04.2015).

Valeur économique du Parc national des Virunga, WWF International, Gland Suisse 2013. https://assets.wwf.ch/downloads/valeur_economique_du_parc_national_des_virunga lr.pdf (dostęp 25.04.2015).

Zalewska M.E., Jak mierzyć zrównoważony rozwój Polski?, w: Modele ustroju społeczno-gospodarczego Kontrowersje i dylematy, red. E. Mączyńska, PTE, Warszawa 2015.

Zalewska M.E., Zrównoważona konsumpcja i produkcja - nierówności w krajach Unii Europejskiej, w: ,,Nierówności Społeczne a Wzrost Gospodarczy”, z. 42 (2), Uniwersytet Rzeszowski, Rzeszów 2015.

Zalewski A., Metody oceny projektów inwestycyjnych, w Ocena $i$ wycena zasobów przyrodniczych, red. J. Szyszko, J. Rylke, P. Jeżewski, I. Dymitryszyn, Wydawnictwo Szkoły Głównej Gospodarstwa Wiejskiego, Warszawa 2013.

\title{
IN SEARCH FOR EFFECTIVENESS OF INVESTMENTS FOR THE ENVIRONMENT MEASURES
}

\begin{abstract}
This paper outlines the issues related to effectiveness of investments for the environment measures. The relations between society and the environment are sketched, taking into account systems of indicators describing these relationships. Attention is drawn to the usefulness of explicitly take into account the investment for the environment, as one of the aspects of the relationship between society and the environment. The article concludes with a case study, which demonstrated that even such an extensive database as Eurostat, is not sufficient to assess the effectiveness of environmental investments at the level of countries.
\end{abstract}

Translated by Mariola Zalewska

Keywords: system of indicators, investment efficiency, environment, sustainable development JEL codes: Q01, O57, C82 